\title{
Response of Night-Blooming Jessamine (Cestrum nocturnum L.) Plants to Phosphorus-Zinc Relation. \\ 1-Growth, Flowering and Uptake of Phosphorous and Zinc.
}

\author{
Ismail H. El-Sallami and Mohamed M. Gad*
}

\author{
Ornamental Plants Dept., Fac. Agric., Assiut University
}

*Mohamed.mohamed1@agr.au.edu.eg

Received on: 9/5/2017

Accepted for publication on: 23/5/2017

\section{Abstract}

Night blooming jessamine (Cestrum nocturnum L.) plants were grown in pots to study $\mathrm{P}-\mathrm{Zn}$ relations as the behavior of both $\mathrm{P}$ and $\mathrm{Zn}$ affecting the absorption of each other by the plant that reflect on growth and flowering. Phosphorus was applied to soil at rates of 0 to $560 \mathrm{ppm}$ with addition of $\mathrm{Zn}$ at rates of 0 to $48 \mathrm{ppm}$.

Greatest plant height, branch number, flowering (earliness and duration) and maximum dry weight accumulation in the different plant parts were occurred by the combination of $280 \mathrm{ppm} \mathrm{P}$ and $24 \mathrm{ppm} \mathrm{Zn}$ applied. In the absence of added $\mathrm{P}$, shoot/root ratio was increased with increasing $\mathrm{Zn}$ level up to $24 \mathrm{ppm}$. Phosphorus at 70 and 560 ppm with $\mathrm{Zn}$ levels, this ratio was a nearly constant, while $\mathrm{P}$ at 140 and $280 \mathrm{ppm}$ with low $\mathrm{Zn}$ level added, the ratio was decreased.

Total uptake of $\mathrm{P}$ and $\mathrm{Zn}$ indicated that $\mathrm{P}$ and $\mathrm{Zn}$ fertilization had altered the uptake of both nutrients by the plant. Total uptake of $P$ was increased by high $\mathrm{P}$ and low $\mathrm{Zn}$. Total Zinc uptake varied opposite to that of $\mathrm{P}$. The maximum of $\mathrm{P}$ and $\mathrm{Zn}$ were obtained by $\mathrm{P}_{280} \mathrm{Zn}_{24}$ as the greatest growth and flowering occurred.

Keywords: Night-blooming jessamine, $P$ applied, Zn applied, Growth and Flowering, $P$ uptake, Zn uptake, P-Zn interaction.

\section{Introduction}

Night-blooming jessamine (Cestrum nocturnum L.) plants are among the most useful of bright-flowering shrubby greenhouse plants grown as pot-plants for their heavy bright small tubular creamy yellow flowers very fragrant by night, they blossoms several times in the summer.

The favorable effects of $\mathrm{P}$ fertilization on growth and flowering were investigated by numerous researchers on many plants such as chrysanthemum (Kato and Takel, 1989), gerbera (Mohamed, 1992), violet and florists cineraria (ElSallami, 1996 \& 2001), prunus (Balal et al., 2011) and strawberry (Mo- hamed et al., 2011). Other works concluded that adequate $\mathrm{Zn}$ nutrition is essential for more vigorous plants and had better growth and quality than other plants severely $\mathrm{Zn}$ deficient (Moraghan and Grafton, 2003; Mirvat et al., 2006; Nasiri et al., 2010; Carolina et al., 2011 and Obaid and Al-Hadethi, 2013).

In early study it is found that supplying the large amounts of phosphorus to night-blooming jessamine plants led to deficiency-stunted growth of leaves associated with zinc deficiency symptoms. Phosphorus is the most important element interferes with $\mathrm{Zn}$ uptake by plants. Zinc absorption capacity is reduced by high 
$\mathrm{P}$ fertilization and $\mathrm{Zn}$ in plant and soil has an antagonism state with phosphorus. About the interaction of $\mathrm{P}$ and $\mathrm{Zn}$ numerous studies have been done and most of them found that high $\mathrm{P}$ applications increase the severity of $\mathrm{Zn}$ deficiency symptoms in plants (Bukvicl et al., 2003; Das et al., 2005; Barben et al., 2010 and Mousavi, 2011). Effects of various treatments of $\mathrm{P}$ and $\mathrm{Zn}$ concluded that $\mathrm{Zn}$ is essential to phosphate utilization by the plants. Increase in phosphate concentration with low Zn level in the soil was considerable, particularly in the early stages of growth (Stukenholts et al., 1966; Sharma et al., 1968 and Khan and Zende, 1977). Applying $\mathrm{Zn}$ to plants grown under potentially $\mathrm{Zn}$-deficient soils is effective in reducing uptake and accumulation of $\mathrm{P}$ in plants (Cakmak and Marschner, 1987 and Mousavi, 2011). Lu et al., (1998) demonstrated that an increase in $\mathrm{P}$ availability did not cause a significant decrease in $\mathrm{Zn}$ concentration in oilseed rape (Brassica napus). Therefore, it remains unclear whether an increase in $\mathrm{P}$ availability in the growth medium can reduce $\mathrm{Zn}$ uptake by plant roots. Huang et al., (2000) observed that $\mathrm{Zn}$ deficiency causes an increase in the expression of $\mathrm{P}$ uptake in barley roots. So the present experiment was undertaken to investigate the interactive effects of $\mathrm{P}$ and $\mathrm{Zn}$ supply at different rates on plant growth, flowering and plant uptakeof $\mathrm{P}$ and $\mathrm{Zn}$ in night-blooming jessamine that will define the optimum use of $\mathrm{P}$ and $\mathrm{Zn}$ fertilizers for balanced nutrition and consequently improvement in plant growth and flowering.

\section{Materials and Methods}

Night-blooming jessamine (Cestrum nocturnum, L.) plants were grown under saran house conditions (30\% light) at the Experimental Farm of Assiut University, Egypt, during two successive seasons of 2012 and 2013.

On March $20^{\text {th }}$ of both seasons, healthy and vigorous plants (oneyear-old) were carefully selected as being uniform in their size (30-32 cm in height). Plants were grown singly in plastic pots, each pot $(4.5 l)$ contained $4.2 \mathrm{~kg}$ air-dried clay soil, sieved through a $0.6 \mathrm{~cm}$ screen. Soil analysis showed; $\mathrm{pH}=7.9(1: 1$ soil to water suspension), $\mathrm{CaCO}_{3}=3.86 \%$, O.M. $=1.43 \%$.C.E.C. $=56.4 \mathrm{mg} / 100 \mathrm{~g}$, Olsen-P $=28.6$ ppm, and DTPAextractable $\mathrm{Zn}, \mathrm{Fe}$ and $\mathrm{Mn}$ were 1.1, 11.7 and 23.2 ppm, respectively.

Phosphorus was added as $\mathrm{NH}_{4} \mathrm{H}_{2} \mathrm{PO}_{4}$ at $0,70,140,280$ or 560 ppm and thoroughly mixed into the soil. Zinc was applied as $\mathrm{ZnSO}_{4}$ at 0 , $6,12,24$ or 48 ppm. All pots received applications of $300 \mathrm{ppm}$ nitrogen as $\mathrm{NH}_{4} \mathrm{NO}_{3}$ and 200 ppm potassium as $\mathrm{K}_{2} \mathrm{SO}_{4}$ such amounts considered to be adequate. Potassium was mixed uniformly with the soil and the $\mathrm{N}$ and $\mathrm{Zn}$ were placed in a layer $5 \mathrm{~cm}$ below the surface of the soil. Pots were irrigated with sufficient water to bring the soil to its field capacity during the growth period.

The experiment had 25 treatments ( $5 \mathrm{P} \times 5 \mathrm{Zn}$ ) consisting of a factorial combination. The treatments were arranged in a randomized complete block design with four replications.

Data of plant height and number of branches per plant were recorded on October of both seasons. Days to 
anthesis were calculated from the date that plants were potted till the first flower opened. Flowering period was recorded when the first flower opened till the closing of flowering. On October $20^{\text {th }}$ of both seasons, selected samples of plants from different treatments were cut $1-\mathrm{cm}$ above soil surface and separated into leaves, stems and roots. All samples were thoroughly washed immediately, oven dried at $70^{\circ} \mathrm{C}$ for $24 \mathrm{hr}$., and dry weight recorded.Shoot/root ratio was calculated by dividing total dry weight of the aerial parts by the dry weight of roots. The dried plant parts were ground in a stainless steel Wiley mill preparatory to wet ashing with nitric-perchloric acid procedure. Phosphorus was determined colorimetrically as phosphomolybdate according to Jackson (1978). Zinc was estimated by atomic absorption spectrophotometer system, PerkinElmer Model 3100.

Phosphorus and zinc uptake by plant parts per unit dry weight were determined. Data were statistically analyzed using SAS software and the means were compared using a least significant difference test according to Dawdy and Wearden(1983).

\section{Results and Discussion}

In the absence of added phosphate, symptoms of $\mathrm{P}$ deficiencystunted plants with small dark-green leaves-developed early in the growth period in the $\mathrm{P}_{0}$-treatment, was more pronounced at the highest $\mathrm{Zn}$ levels. Symptoms of Zn deficiency-retarded stem and leaf growth and crinkled chlorotic leaves-appeared in P-treated plants without $\mathrm{Zn}$ fertilizer in the $\mathrm{Zn}_{0}$ series, but only at the highest phosphate levels.

\section{Plant height and number of} branches per plant

Data presented in Table 1 reveled that, phosphorous and zinc treatments produced taller plants and more branches per plantthan controls $\left(\mathrm{P}_{0}\right.$ and $\left.\mathrm{Zn}_{0}\right)$. The tallest plants with maximum number of branches were obtained by applications of phosphorous at $280 \mathrm{ppm}$ and zinc at $24 \mathrm{ppm}$. These results are in agreement with those found by Omer (1992) on Tagetespatula and El-Sallami (2001) on Seneciaocruentus, L.

Table 1. Effect of $P$ and $\mathrm{Zn}$ fertilization on plant height and number of branches per plant of Night-Blooming Jessamine during 2012 and 2013 seasons.

\begin{tabular}{|c|c|c|c|c|c|c|c|c|c|c|c|c|}
\hline \multirow{4}{*}{$\begin{array}{l}\text { P level } \\
\text { (ppm). }\end{array}$} & \multicolumn{12}{|c|}{ Plant height (cm) } \\
\hline & \multicolumn{6}{|c|}{2012 Season } & \multicolumn{6}{|c|}{2013 Season } \\
\hline & \multicolumn{6}{|c|}{ Zn level (ppm) } & \multicolumn{6}{|c|}{ Zn level (ppm) } \\
\hline & $\mathbf{0}$ & 6 & 12 & 24 & 48 & Mean & $\mathbf{0}$ & 6 & 12 & 24 & 48 & Mean \\
\hline $\mathbf{0}$ & 66.30 & 74.20 & 77.60 & 82.50 & 71.70 & 74.50 & 63.90 & 76.40 & 79.20 & 87.30 & 73.80 & 76.10 \\
\hline 70 & 71.80 & 81.00 & 85.70 & 93.80 & 76.20 & 81.70 & 70.10 & 83.70 & 88.60 & 99.70 & 75.40 & 83.50 \\
\hline 140 & 76.00 & 83.60 & 84.50 & 94.90 & 86.50 & 85.10 & 78.30 & 86.70 & 89.00 & 98.10 & 84.50 & 87.30 \\
\hline 280 & 80.60 & 87.30 & 98.70 & 107.0 & 88.10 & 92.30 & 82.60 & 90.10 & 97.80 & 118.2 & 90.30 & 95.80 \\
\hline 560 & 76.60 & 75.40 & 78.60 & 83.70 & 81.20 & 77.30 & 74.30 & 86.50 & 81.30 & 89.30 & 72.60 & 80.80 \\
\hline Mean & 74.26 & 80.30 & 85.02 & 92.38 & 80.74 & & 73.84 & 84.68 & 87.18 & 98.52 & 79.32 & \\
\hline $\begin{array}{c}\text { L.S.D. } \\
0.05\end{array}$ & \multicolumn{6}{|c|}{ P:5.16 Zn: 4.67Px Zn: 10.44} & \multicolumn{6}{|c|}{ P: 4.40 $\quad Z n:$ 4.45Px Zn: 9.96} \\
\hline \multicolumn{13}{|c|}{ Branch No./plant } \\
\hline $\mathbf{0}$ & 5.25 & 6.50 & 7.25 & 8.75 & 6.00 & 6.75 & 5.65 & 6.25 & 6.75 & 8.25 & 6.00 & 6.58 \\
\hline 70 & 6.50 & 8.50 & 9.75 & 10.75 & 7.00 & 8.50 & 6.25 & 8.00 & 8.50 & 9.50 & 7.25 & 7.90 \\
\hline 140 & 8.00 & 9.75 & 10.25 & 13.75 & 9.50 & 10.25 & 7.50 & 9.25 & 9.75 & 11.50 & 8.25 & 9.25 \\
\hline 280 & 10.50 & 11.00 & 12.50 & 16.50 & 10.75 & 12.25 & 9.25 & 10.25 & 12.00 & 16.75 & 10.75 & 11.80 \\
\hline 560 & 7.25 & 8.00 & 9.50 & 12.50 & 7.75 & 9.00 & 6.75 & 7.25 & 9.50 & 11.50 & 7.00 & 8.40 \\
\hline Mean & 7.50 & 8.75 & 9.85 & 12.85 & 8.20 & & 7.08 & 8.20 & 9.30 & 11.50 & 7.85 & \\
\hline $\begin{array}{c}\text { L.S.D. } \\
0.05\end{array}$ & \multicolumn{6}{|c|}{ P: $0.94 \quad Z n:$ 0.73Px Zn: 1.64} & \multicolumn{6}{|l|}{ P: 0.89} \\
\hline
\end{tabular}




\section{Earliness and flowering period}

Phosphorous and zinc treatments did not delay anthesis compared to control (Tables 2 and 3). Time required for plants to reach anthesis significantly decreased with increasing levels of applied $\mathrm{P}$ above $70 \mathrm{ppm}$ and $12 \mathrm{ppm}$ or more of $\mathrm{Zn}$ fertilization. Greatest earliness occurred by the combined treatment of $\mathrm{P}_{\mathbf{2 8 0}} \mathrm{Zn}_{\mathbf{2 4}}$ (Table 4) plants averaged 114 and 105 days from planting to anthesis in the first and second seasons, respectively. Numerous workers
(Mohamed, 1992; El-Sallami, 2001 and Mohamed et al., 2011) have also reported that $\mathrm{P}$ and $\mathrm{Zn}$ nutrition at certain rates occurred earliness of visible bud, complete bud formation, complete flowering and increased flower duration of gerbera, florists cineraria and strawberry. Leopold and Kriedemann (1980) stated that greater earliness would refer to an earlier morphological differentiation of flowers and hence to the formation of the first flower primordial at a lower node.

Table 2. Flowering of night-blooming jessamine in relation to $P$ treatments in 2012 and 2013 seasons.

\begin{tabular}{|c|c|c|c|c|}
\hline $\begin{array}{c}\text { P applied, ppm } \\
\text { in soil }\end{array}$ & \multicolumn{2}{|c|}{ Time from planting to anthesis, days } & \multicolumn{2}{c|}{ Period of flowering, days } \\
\cline { 2 - 5 } & 2012 & 2013 & 2012 & 2013 \\
\hline 0 & 160 & 164 & 37 & 35 \\
\hline 70 & 153 & 151 & 50 & 46 \\
\hline 140 & 146 & 142 & 58 & 54 \\
\hline 280 & 131 & 125 & 76 & 81 \\
\hline 560 & 145 & 140 & 56 & 58 \\
\hline LSD at 0.05 & 12 & 14 & 9 & 8 \\
\hline
\end{tabular}

Table 3. Flowering of night-blooming jessamine in relation to $\mathrm{Zn}$ treatments in 2012 and 2013 seasons.

\begin{tabular}{|c|c|c|c|c|}
\hline \multirow{2}{*}{$\begin{array}{l}\text { Zn applied, } \\
\text { ppm in soil }\end{array}$} & \multicolumn{2}{|c|}{ Time from planting to anthesis, days } & \multicolumn{2}{c|}{ Period of flowering, days } \\
\cline { 2 - 5 } & 2012 & 2013 & 2012 & 2013 \\
\hline 0 & 158 & 157 & 48 & 48 \\
\hline 6 & 154 & 151 & 51 & 53 \\
\hline 12 & 146 & 143 & 56 & 55 \\
\hline 24 & 133 & 129 & 65 & 64 \\
\hline 48 & 144 & 141 & 57 & 54 \\
\hline LSD at 0.05 & 12 & 14 & 9 & 8 \\
\hline
\end{tabular}

All P treatment significantly increased flowering period compared to control. Meanwhile, $\mathrm{Zn}$ at $24 \mathrm{ppm}$ was more effective concentration in this respect. No considerable response in flowering period of nightblooming jessamine was obtained from applied $\mathrm{Zn}$ less or more than 24 ppm, in most cases. Higher response in flowering period was obviously taking place with the combination of $\mathrm{P}_{280} \mathrm{Zn}_{24}$ (Table 4) as recorded longer flowering period by 57 and 67 days than control $\left(\mathrm{P}_{0} \mathrm{Zn}_{0}\right)$ in the first and second seasons, respectively.

Apparently, flowering time and period are strongly influenced by subhigher levels of $\mathrm{P}$ and $\mathrm{Zn}$ fertilizers (optimum levels $\mathrm{P}_{\mathbf{2 8 0}} \mathrm{Zn}_{\mathbf{2 4}}$ ). The most recognized problem of $\mathrm{Zn}$ deficiency 
is its antagonistic effect upon P. The present result indicates that earliness and flowering period of nightblooming jessamine were best when $\mathrm{P}$ fertilizer level would be consideredhigh by as much as 11.7 times to $\mathrm{Zn}$ added. At both ideal levels $\left(\mathrm{P}_{\mathbf{2 8 0}}\right.$ $\mathrm{Zn}_{24}$, plant roots are able to absorb $\mathrm{P}$ and $\mathrm{Zn}$ adequately as translocation of each other enhanced from roots to the upper plant parts. The favourable ef- fect of $P$ fertilization was investigated by numerous researchers on flowering of some ornamentals such as chrysanthemum (Kato and Takel, 1989), gerbera (Mohamed, 1992) and violet (El-Sallami, 1996). Other scientists reported the promotive effect of $\mathrm{Zn}$ on flowering of marigold (Omer, 1992), narcissus (El-Sallami, 1997) and chamomile (Nasiri et al., 2010).

Table 4. Flowering of night-blooming jessamine in relation to $P$ and $\mathrm{Zn}$ fertilization in 2012 and 2013 seasons.

\begin{tabular}{|c|c|c|c|c|c|}
\hline \multirow{2}{*}{$\begin{array}{l}P \text { applied, } \\
\text { ppm in soil }\end{array}$} & \multirow{2}{*}{$\begin{array}{l}\text { Zn applied, } \\
\text { ppm in soil }\end{array}$} & \multicolumn{2}{|c|}{$\begin{array}{l}\text { Time from planting to anthe- } \\
\text { sis, days }\end{array}$} & \multicolumn{2}{|c|}{ Period of flowering, days } \\
\hline & & 2012 & 2013 & 2012 & 2013 \\
\hline & 0 & 167 & 172 & 34 & 32 \\
\hline & 6 & 166 & 170 & 37 & 34 \\
\hline \multirow[t]{5}{*}{0} & 12 & 158 & 165 & 37 & 35 \\
\hline & 24 & 147 & 152 & 39 & 38 \\
\hline & 48 & 162 & 160 & 38 & 37 \\
\hline & 0 & 165 & 162 & 40 & 42 \\
\hline & 6 & 159 & 158 & 47 & 43 \\
\hline \multirow[t]{5}{*}{70} & 12 & 154 & 154 & 51 & 46 \\
\hline & 24 & 141 & 138 & 62 & 57 \\
\hline & 48 & 146 & 142 & 52 & 43 \\
\hline & 0 & 158 & 155 & 52 & 49 \\
\hline & 6 & 157 & 153 & 53 & 52 \\
\hline \multirow[t]{5}{*}{140} & 12 & 140 & 136 & 62 & 58 \\
\hline & 24 & 135 & 130 & 68 & 59 \\
\hline & 48 & 141 & 137 & 56 & 52 \\
\hline & 0 & 136 & 140 & 68 & 67 \\
\hline & 6 & 133 & 129 & 73 & 76 \\
\hline \multirow[t]{5}{*}{280} & 12 & 138 & 123 & 72 & 81 \\
\hline & 24 & 114 & 105 & 91 & 99 \\
\hline & 48 & 134 & 128 & 76 & 80 \\
\hline & 0 & 162 & 156 & 48 & 50 \\
\hline & 6 & 156 & 147 & 44 & 58 \\
\hline \multirow[t]{3}{*}{560} & 12 & 142 & 137 & 59 & 57 \\
\hline & 24 & 128 & 121 & 67 & 69 \\
\hline & 48 & 136 & 140 & 63 & 57 \\
\hline LSD at 0.05 & & 26 & 31 & 20 & 18 \\
\hline
\end{tabular}

\section{Dry weight accumulation}

Data on dry weight accumulation in different plant parts are listed in Tables (5 and 6). Apparently, weight of plant parts were increased by varying the proportions of $\mathrm{P}$ and Zn.
All $\mathrm{P}$ treatments significantly increased dry weight accumulation in leaves and roots compared to control, while $\mathrm{P}$ levels at 140 to $560 \mathrm{ppm}$ were more effective than $\mathrm{P}_{70}$ in stem dry weight. The greatest increase in dry weights of different plant parts 
were caused by $\mathrm{P}_{280}$, however, averaging 70, 48 and 58\% over control plants in leaves, stems and roots, respectively. $\mathrm{P}$ fertilization treatments showed similar pattern in total dry weight of whole plant to that of plant parts, the heaviest weight was occurred by $\mathrm{P}_{280}$ achieved 56 and $50 \%$ more than control plants in $1^{\text {st }}$ and $2^{\text {nd }}$ seasons, respectively (Table 7). Similar results are in accordance with those reported by other investigators (Kato and Takel, 1989; El-Sallami, 2001; Mirvat et al., 2006; Khorgamy and Farnia, 2009; Balal et al., 2011 and Mohamed et al., 2011).

All $\mathrm{Zn}$ levels significantly increased leaf, stem and root dry weights, except $\mathrm{Zn}_{48}$ did not affect root weight. Maximum increases were obtained by $\mathrm{Zn}_{24}$ averaged 67 , 83 and 51\% over control plants in leaves, stems and roots, respectively. Either $\mathrm{Zn}_{12}$ or $\mathrm{Zn}_{24}$ significantly increased total dry weight of plants in comparison with $\mathrm{Zn}_{0}, \mathrm{Zn}_{12}$ and $\mathrm{Zn}_{48}$ (Table 8). However, $\mathrm{Zn}_{24}$ was much greater than $\mathrm{Zn}_{12}$, resulting 76 and $71 \%$ over control plants in $1^{\text {st }}$ and $2^{\text {nd }}$ seasons, respectively. The favorable effects of $\mathrm{Zn}$ on growth was concluded by numerous reports (Dell and Wilson, 1985; Webb and Loneagan, 1988; Moraghan and Grafton, 2003; Kinaci and Kinaci, 2005; Khorgamy and Farnia, 2009; Nasiriet al., 2010; Carolina et al., 2011; Mohamed et al., 2011; Mousavi, 2011 and Obaid and Al-Hadethi, 2013).

The presence of phosphorous at various concentrations, along with $\mathrm{Zn}$ in the soil helped plant growth to attain normal or higher values as compared to control. Similar observations were reported by other workers (ElGharably and Rushdi, 1975; Fageria, 2001; Bukviclet al., 2003; Mirvat, 2006; Khorgamy and Farnia, 2009 and Mohamed et al., 2011).

Maximum growth occurred at $\mathrm{P}_{280} \mathrm{Zn}_{24}$ (Table 7) interpretation of growth and nutrient uptake is difficult because $\mathrm{P}$ and $\mathrm{Zn}$ were varying simultaneously. In the discussion that follows $\mathrm{P}$ deficiency was interpreted as limiting growth below $\mathrm{P}_{\mathbf{2 8 0}} \mathrm{Zn}_{\mathbf{2 4}}$. Above this level $\mathrm{Zn}$ deficiency was concluded to have limited growth of night-blooming jessamine plants.

Table 5. Dry weight of leaves of night-blooming jessamine in relation to $P$ and $Z n$ fertilization in 2012 and 2013 seasons.

\begin{tabular}{|c|c|c|c|c|c|c|c|c|c|c|c|c|}
\hline \multirow{4}{*}{$\begin{array}{l}\text { P ap- } \\
\text { plied, } \\
\text { ppm } \\
\text { in soil }\end{array}$} & \multicolumn{12}{|c|}{ Dry weight of leaves, $\mathrm{g} / \mathrm{plant}$} \\
\hline & \multicolumn{12}{|c|}{ Zn applied, ppm in soil } \\
\hline & $\mathbf{0}$ & 6 & 12 & 24 & 48 & \multirow{2}{*}{ Mean } & $\mathbf{0}$ & 6 & 12 & 24 & 48 & \multirow[b]{2}{*}{ Mean } \\
\hline & \multicolumn{5}{|c|}{2012} & & \multicolumn{5}{|c|}{2013} & \\
\hline 0 & 4.52 & 5.88 & 6.05 & 9.04 & 8.51 & 6.80 & 4.96 & 6.51 & 6.70 & 9.82 & 8.39 & 7.28 \\
\hline 70 & 5.57 & 8.30 & 9.38 & 12.70 & 8.65 & 8.92 & 5.98 & 9.67 & 10.25 & 13.73 & 10.30 & 9.99 \\
\hline 140 & 7.97 & 10.18 & 10.24 & 14.42 & 11.14 & 10.79 & 9.11 & 10.02 & 10.07 & 15.04 & 11.69 & 11.19 \\
\hline 280 & 8.96 & 10.01 & 11.25 & 14.70 & 11.87 & 11.36 & 10.49 & 12.46 & 11.51 & 15.04 & 12.93 & 12.49 \\
\hline 560 & 9.94 & 10.12 & 10.41 & 12.63 & 11.45 & 10.91 & 10.57 & 10.91 & 10.66 & 12.98 & 11.61 & 11.35 \\
\hline Mean & 7.39 & 8.90 & 9.47 & 12.70 & $\mathbf{1 0 . 3 2}$ & & 8.22 & 9.91 & 9.84 & 13.32 & 10.98 & \\
\hline LSD5\% & \multicolumn{2}{|c|}{$\mathrm{P}=1.48$} & \multicolumn{2}{|c|}{$\mathrm{Zn}=\mathbf{1 . 4 8}$} & \multicolumn{2}{|c|}{$P x Z n=3.31$} & \multicolumn{2}{|c|}{$\mathrm{P}=\mathbf{1 . 6 0}$} & \multicolumn{2}{|c|}{$\mathrm{Zn}=\mathbf{1 . 6 0}$} & \multicolumn{2}{|c|}{$P x Z n=3.57$} \\
\hline
\end{tabular}


Table 6. Dry weight of stems of night-blooming jessamine in relation to $P$ and $\mathrm{Zn}$ fertilization in 2012 and 2013 seasons.

\begin{tabular}{|c|c|c|c|c|c|c|c|c|c|c|c|c|}
\hline \multirow{4}{*}{$\begin{array}{l}\text { P ap- } \\
\text { plied, } \\
\text { ppm } \\
\text { in soil }\end{array}$} & \multicolumn{12}{|c|}{ Dry weight of stems, $\mathrm{g} /$ plant } \\
\hline & \multicolumn{12}{|c|}{ Zn applied, ppm in soil } \\
\hline & $\mathbf{0}$ & 6 & 12 & 24 & 48 & \multirow{2}{*}{ Mean } & $\mathbf{0}$ & 6 & 12 & 24 & 48 & \multirow{2}{*}{ Mean } \\
\hline & \multicolumn{5}{|c|}{2012} & & \multicolumn{5}{|c|}{2013} & \\
\hline 0 & 16.39 & 19.74 & 27.29 & 30.31 & 17.89 & 22.31 & 20.99 & 21.92 & 30.36 & 35.10 & 28.24 & 27.32 \\
\hline 70 & 20.38 & 25.58 & 28.38 & 28.82 & 23.70 & 25.37 & 21.30 & 25.49 & 32.92 & 33.65 & 25.72 & 27.82 \\
\hline 140 & 22.36 & 22.32 & 38.51 & 38.13 & 20.36 & 28.34 & 23.39 & 23.18 & 36.63 & 43.96 & 22.81 & 29.99 \\
\hline 280 & 19.09 & 31.27 & 37.50 & 52.55 & 30.48 & 34.18 & 28.84 & 31.17 & 40.02 & 57.86 & 35.82 & 38.74 \\
\hline 560 & 23.34 & 26.51 & 29.99 & 39.92 & 28.35 & 29.62 & 25.28 & 33.69 & 35.06 & 42.28 & 20.96 & 31.45 \\
\hline Mean & 20.30 & 25.08 & 32.33 & 37.95 & 24.16 & & 23.96 & 27.09 & 35.00 & 42.57 & 26.71 & \\
\hline LSD5\% & \multicolumn{2}{|c|}{$\mathrm{P}=3.82$} & \multicolumn{2}{|c|}{$\mathrm{Zn}=\mathbf{3 . 8 2}$} & \multicolumn{2}{|c|}{$P x Z n=8.53$} & \multicolumn{2}{|c|}{$\mathrm{P}=\mathbf{2 . 6 5}$} & \multicolumn{2}{|c|}{$\mathrm{Zn}=\mathbf{2 . 6 5}$} & \multicolumn{2}{|c|}{$P x Z n=5.92$} \\
\hline
\end{tabular}

Table 7. Dry weight of roots of night-blooming jessamine in relation to $P$ and $\mathrm{Zn}$ fertilization in 2012 and 2013 seasons.

\begin{tabular}{|c|c|c|c|c|c|c|c|c|c|c|c|c|}
\hline \multirow{4}{*}{$\begin{array}{l}\text { P ap- } \\
\text { plied, } \\
\text { ppm } \\
\text { in soil }\end{array}$} & \multicolumn{12}{|c|}{ Dry weight of roots, $g$ /plant } \\
\hline & \multicolumn{12}{|c|}{ Zn applied, ppm in soil } \\
\hline & $\mathbf{0}$ & 6 & 12 & 24 & 48 & \multirow{2}{*}{ Mean } & 0 & 6 & 12 & 24 & 48 & \multirow{2}{*}{ Mean } \\
\hline & \multicolumn{5}{|c|}{2012} & & \multicolumn{5}{|c|}{2013} & \\
\hline 0 & 5.05 & 5.68 & 6.30 & 6.80 & 5.22 & 5.81 & 4.93 & 5.42 & 5.86 & 7.47 & 5.03 & 5.74 \\
\hline 70 & 5.26 & 6.55 & 6.63 & 8.18 & 6.08 & 6.54 & 5.09 & 6.37 & 7.43 & 8.68 & 6.63 & 6.84 \\
\hline 140 & 7.43 & 7.85 & 8.60 & 9.85 & 7.60 & 8.27 & 7.58 & 8.55 & 9.03 & 10.90 & 7.78 & 8.77 \\
\hline 280 & 7.70 & 8.68 & 8.83 & 11.75 & 8.20 & 9.03 & 7.36 & 9.40 & 9.55 & 11.33 & 8.63 & 9.25 \\
\hline 560 & 6.32 & 7.75 & 9.01 & 9.73 & 6.40 & 7.84 & 6.43 & 7.92 & 9.35 & 10.21 & 7.69 & 8.32 \\
\hline Mean & 6.35 & 7.30 & 7.87 & 9.26 & 6.70 & & 6.28 & 7.53 & 8.24 & 9.72 & 7.15 & \\
\hline LSD5\% & \multicolumn{2}{|c|}{$\mathrm{P}=\mathbf{0 . 7 1}$} & \multicolumn{2}{|c|}{$\mathrm{Zn}=\mathbf{0 . 7 1}$} & \multicolumn{2}{|c|}{$\mathrm{Px} Z n=1.59$} & \multicolumn{2}{|c|}{$\mathrm{P}=\mathbf{0 . 9 6}$} & \multicolumn{2}{|c|}{$\mathrm{Zn}=\mathbf{0 . 9 6}$} & \multicolumn{2}{|c|}{$P x Z n=2.14$} \\
\hline
\end{tabular}

Table 8. Dry weight of whole-plant of night-blooming jessamine in relation to $P$ and $\mathrm{Zn}$ fertilization in 2012 and 2013 seasons.

\begin{tabular}{|c|c|c|c|c|c|c|c|c|c|c|c|c|}
\hline \multirow{4}{*}{$\begin{array}{l}\text { P ap- } \\
\text { plied, } \\
\text { ppm } \\
\text { in soil }\end{array}$} & \multicolumn{12}{|c|}{ Dry weight of whole-plant, $\mathrm{g} /$ plant } \\
\hline & \multicolumn{12}{|c|}{ Zn applied, ppm in soil } \\
\hline & $\mathbf{0}$ & 6 & 12 & 24 & 48 & \multirow[b]{2}{*}{ Mean } & $\mathbf{0}$ & 6 & 12 & 24 & 48 & \multirow{2}{*}{ Mean } \\
\hline & \multicolumn{5}{|c|}{2012} & & \multicolumn{5}{|c|}{2013} & \\
\hline 0 & 25.91 & 31.30 & 39.64 & 46.15 & 31.63 & 34.93 & 30.88 & 35.85 & 42.92 & 52.39 & 41.66 & 40.34 \\
\hline 70 & 31.21 & 40.43 & 44.39 & 49.70 & 38.44 & 40.83 & 32.38 & 41.53 & 50.60 & 56.06 & 42.65 & 44.64 \\
\hline 140 & 37.76 & 40.35 & 57.35 & 62.40 & 39.10 & 47.39 & 40.08 & 41.75 & 55.74 & 69.90 & 42.28 & 49.95 \\
\hline 280 & 35.75 & 49.97 & 57.58 & 79.00 & 50.55 & 54.57 & 46.69 & 53.03 & 61.08 & 84.24 & 57.38 & 60.48 \\
\hline 560 & 39.60 & 44.38 & 49.41 & 62.28 & 46.20 & 48.37 & 42.28 & 52.52 & 55.07 & 65.47 & 40.26 & 51.12 \\
\hline Mean & 34.05 & 41.27 & 49.67 & 59.91 & \begin{tabular}{|l|}
41.18 \\
\end{tabular} & & 38.46 & 44.54 & 53.08 & 65.61 & 44.85 & \\
\hline LSD5\% & \multicolumn{2}{|c|}{$\mathrm{P}=\mathbf{8 . 4 8}$} & \multicolumn{2}{|c|}{$\mathrm{Zn}=\mathbf{8 . 4 8}$} & \multicolumn{2}{|c|}{$P x Z n=18.94$} & \multicolumn{2}{|c|}{$\mathrm{P}=\mathbf{8 . 2 2}$} & \multicolumn{2}{|c|}{$\mathrm{Zn}=\mathbf{8 . 2 2}$} & \multicolumn{2}{|c|}{$P x Z n=18.36$} \\
\hline
\end{tabular}

\section{Shoot/root ratio}

In the absence of added $P$ shoot/root ratio was increased with increasing $\mathrm{Zn}$ level from 0 to $48 \mathrm{ppm}$; Fig. 1. The increase in this ratio might be considered evidence of the beneficial effect of $\mathrm{Zn}$ on stimulating the vegetative growth at the expense of root growth. El-Sallami (2001) also reported similar observations with the florists cineraria. Phosphorus at 140 and $280 \mathrm{ppm}$ with high $\mathrm{Zn}$ levels, the ratio averaging 5.3, while with lower or no added $\mathrm{Zn}$, the ratio was a lesser degree (4.3). The combinations of $\mathrm{P}_{\mathbf{7 0}}$ and $\mathrm{P}_{\mathbf{5 6 0}}$ with $\mathrm{Zn}$ levels showed a nearly constant ratio within the shoot and root weight. The implications of this parallel effect of these combinations on growth of shoot and root are not clear. 

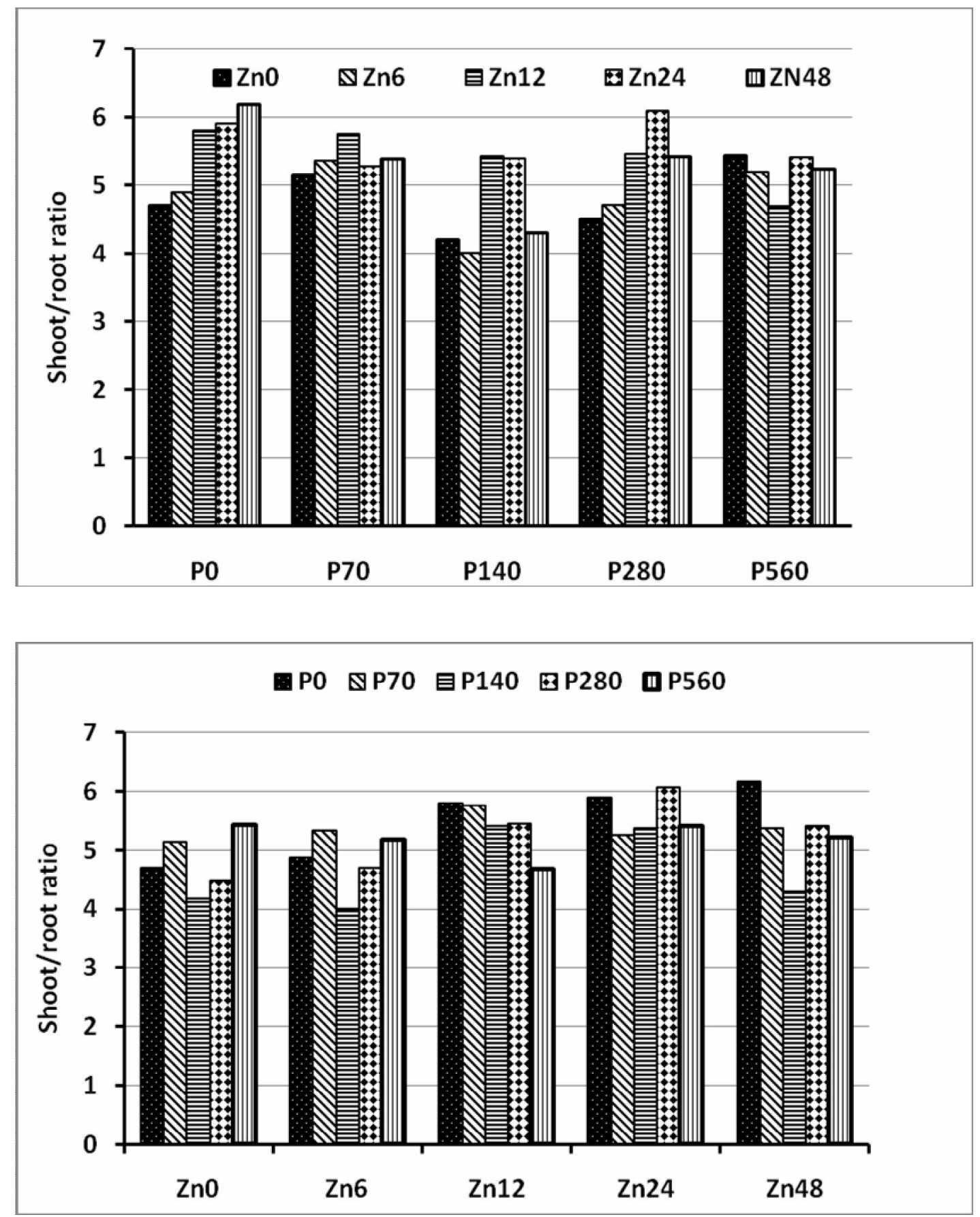

Fig.1. Shoot/root ratio as influenced by $P$ and $\mathrm{Zn}$ fertilization (average of both seasons). 


\section{Uptake of $P$ by plant parts}

Adding $\mathrm{P}$ treatments consistently and markedly increased $\mathrm{P}$ uptake. As expected, high $\mathrm{P}$ level resulted in greater proportions of $\mathrm{P}$ remaining in all plant parts (Fig. 2). High $\mathrm{P}$ uptake may involve a high rate of $\mathrm{P}$ transport from root to shoot via the xylem, and this may hinder $\mathrm{Zn}$ uptake and translocation, as the proportion of $\mathrm{Zn}$ uptake by plant parts were consistently lower. Zinc application without added $\mathrm{P}$ show that $\mathrm{P}$ uptake was considerably increased as $\mathrm{Zn}$ supply raised up to $24 \mathrm{ppm}$ in all parts. This indicate that low Zn supplies caused an increase in the proportion of total $\mathrm{P}$ uptake. Excess $\mathrm{Zn}$ addition $\left(\mathrm{Zn}_{48}\right)$ has a reduction on $\mathrm{P}$ uptake by plant. With no $\mathrm{Zn}$ applied, total $\mathrm{P}$ uptake by plant parts was $96 \%$ greater in the presence of 560ppm $\mathrm{P}$ than in the presence of $48 \mathrm{ppm} \mathrm{Zn}$ without $\mathrm{P}$ added. This clearly suggests that $\mathrm{Zn}$ application has decreased the uptake of $\mathrm{P}$ from soil. In general, total uptake of $\mathrm{P}$ by stems was much greater than by leaves or roots.

\section{Uptake of Zn by plant parts}

Zinc uptake without $\mathrm{P}$ supply showed greater responses to $\mathrm{Zn}$ fertil- izer in all plant parts as increased with increasing $\mathrm{Zn}$ level (Fig. 3). The degree of response to $\mathrm{Zn}$ uptake under the utilization of $\mathrm{P}$ fertilizer was varied with the levels of $P$. With no $P$ applied, total Zn uptake by plant parts at $\mathrm{Zn}{ }_{48}$ level was about twice that of $\mathrm{P}_{560}$ without $\mathrm{Zn}$ added. Large application of fertilizer $\mathrm{P}$ to soil that are low in available $\mathrm{Zn}$ can depress $\mathrm{Zn}$ uptake.Increase in $\mathrm{Zn}$ uptake with low soil $\mathrm{P}$ availability over high $\mathrm{P}$ availability, and the inverse relationship between each of $\mathrm{P}$ and $\mathrm{Zn}$ uptake. The uptake of $\mathrm{Zn}$ under $\mathrm{P}_{560}$ treatment is lower than under $\mathrm{P}_{0}$ in all plant parts. Such reduction in $\mathrm{Zn}$ uptake by roots, stems and leaves were 32, 51 and $36 \%$, respectively. The present results cleared that an increase in available soil $\mathrm{P}$ was associated with lower Zn uptake by plant which is in general agreed with the finding of Gianquinto et al (2000). They explained that the $\mathrm{P}$-induced decrease in $\mathrm{Zn}$ concentration is caused by a dilution effect of increased shoot growth rather than by reduced $\mathrm{Zn}$ uptake by roots. 


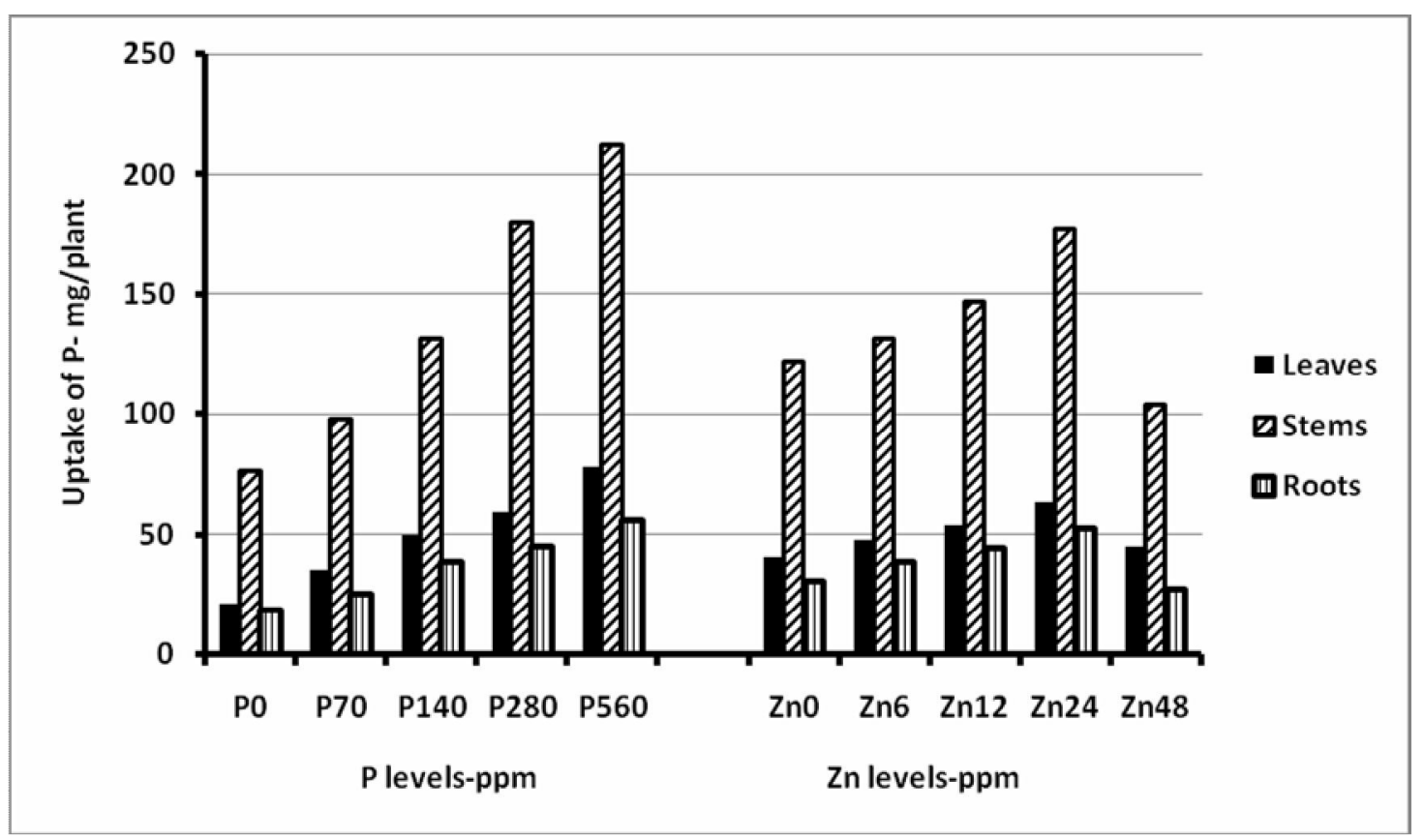

Fig.2. Effect of $P$ and $Z n$ fertilization on average uptake of $P$ by roots, stems and leaves of night- blooming jessamine

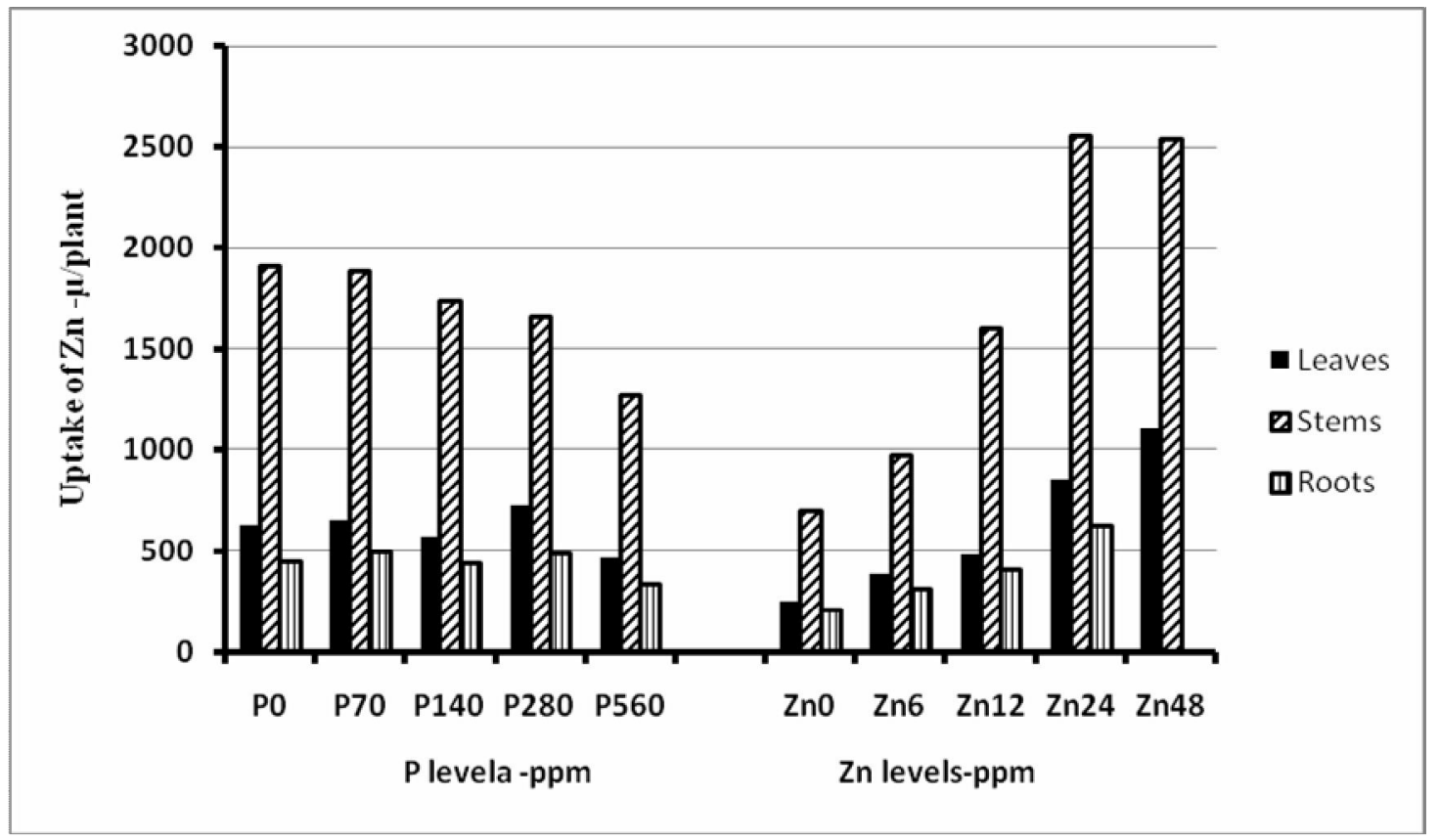

Fig.3. Effect of $P$ and $\mathrm{Zn}$ fertilization on average uptake of $\mathrm{Zn}$ by roots, stems and leaves of night-blooming jessamine. 


\section{Relationship between total $P$ up- take and total $\mathrm{Zn}$ uptake}

Total Phosphorus uptake was increased with increasing $\mathrm{P}$ level in the soil while total $\mathrm{Zn}$ uptake remained relatively unchanged from 0 to $280 \mathrm{ppm} \mathrm{P}$ but was continued to decrease as $\mathrm{P}$ level increased (Fig. 5). The point of inflection for both total $\mathrm{P}$ and total $\mathrm{Zn}$ distribution occurred seldom above $280 \mathrm{ppm} \mathrm{P}$ where greatest growth occurred. This indicated that the adverse effects of high $\mathrm{P}$ and low $\mathrm{Zn}$ were already being shown within the plant. Perhaps the adverse effects of high $\mathrm{P}$ and low $\mathrm{Zn}$ may well begin to limit growth after plants obtain enough $\mathrm{P}$ and $\mathrm{Zn}$ for maximum growth. This was consistent with results obtained by ElSallami (2001), Balal et al. (2011) and Mousavi (2011) showing that $P$ and $\mathrm{Zn}$ reacted together to reduce the uptake by plant. Barben et al. (2010) reported that the main effect of $\mathrm{P}$ and $\mathrm{Zn}$ was "a physiological inhibition in the translocation of $\mathrm{Zn}$ from roots to tops". Bukvicl et al. (2003) concluded that a high level of $\mathrm{P}$ in the soil either reduces the solubility of $\mathrm{Zn}$ or interferes with the movement of $\mathrm{Zn}$ to its functional location in the plant.
Total phosphorus and total zinc uptake as influenced by added $\mathrm{Zn}$ were continued to increase as $\mathrm{Zn}$ level increased up to $24 \mathrm{ppm}$, however total $\mathrm{P}$ uptake was the maximum where the optimum growth occurred (Fig. 5). Above $24 \mathrm{ppm} \mathrm{Zn,} \mathrm{total}$ phosphorus uptake dropped, on contrast, total Zn uptake slightly increased. The point of inflection for both $\mathrm{P}$ and $\mathrm{Zn}$ distribution occurred at 24 ppm Zn where greatest growth obtained. This explained that the adverse effects of high $\mathrm{Zn}$ and low $\mathrm{P}$ may begin to limit growth after plants obtain enough $\mathrm{P}$ and $\mathrm{Zn}$ for maximum growth. This can only be relieved by supplying $\mathrm{Zn}$. At maximum growth $\left(\mathrm{P}_{280} \mathrm{Zn}_{24}\right)$, although $\mathrm{Zn}$ applied at $24 \mathrm{ppm}$ had little effect on total $\mathrm{P}$ uptake, total $\mathrm{Zn}$ uptake by plant increased to approximately $42 \%$ more than in the presence of added $\mathrm{P}$ at $280 \mathrm{ppm}$.

Data obtained showed a considerable evidence for an antagonistic interaction between $\mathrm{P}$ and $\mathrm{Zn}$ concerning their absorption, a decreased uptake of $\mathrm{Zn}$ as the $\mathrm{P}$ level is increased, and a decreased $\mathrm{P}$ uptake as the $\mathrm{Zn}$ level is increased. 


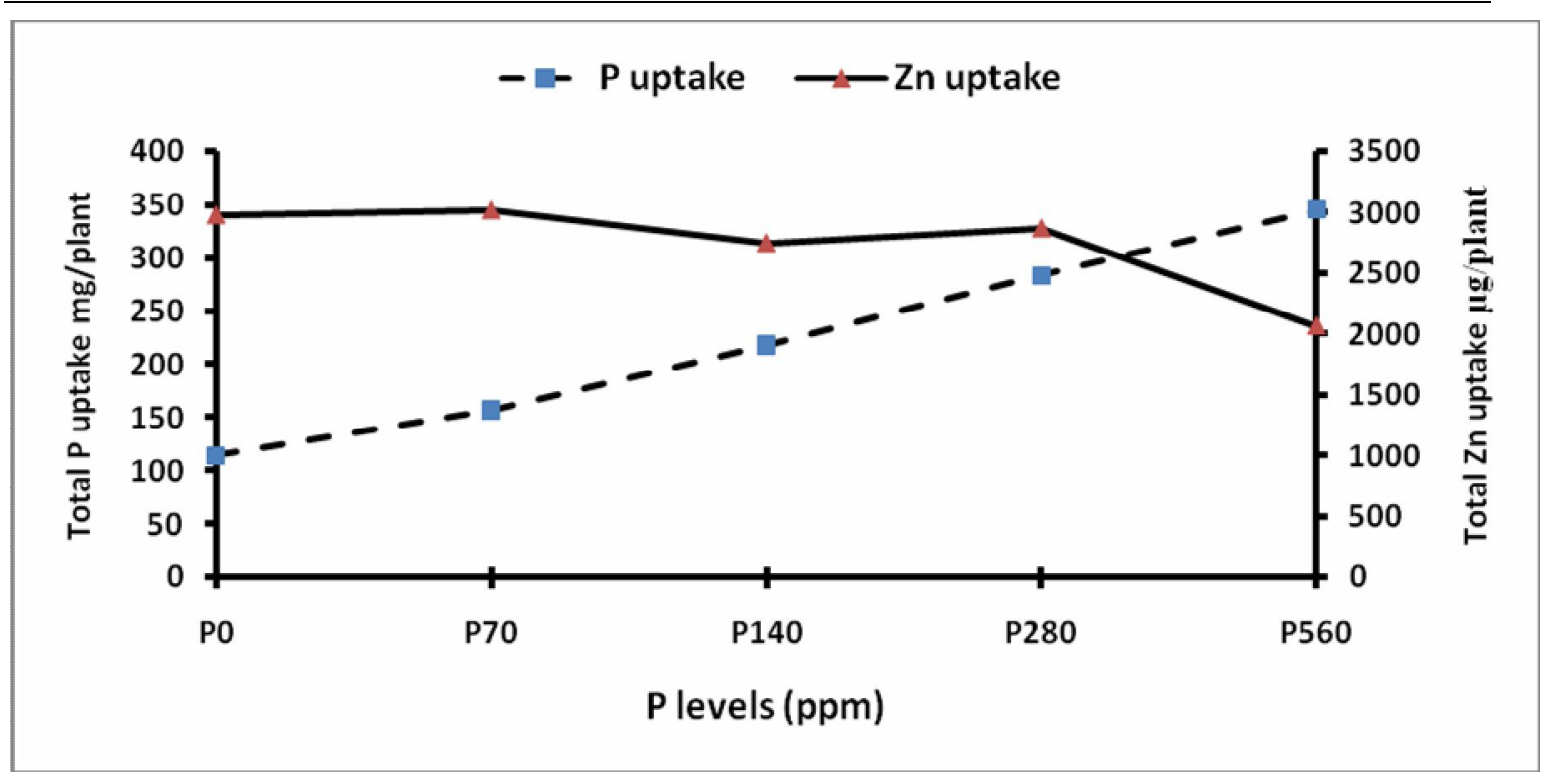

Fig.4. Relationship between total $P$ and total $\mathrm{Zn}$ uptake by plant of ight- blooming jessamine as influenced by $P$ fertilization.

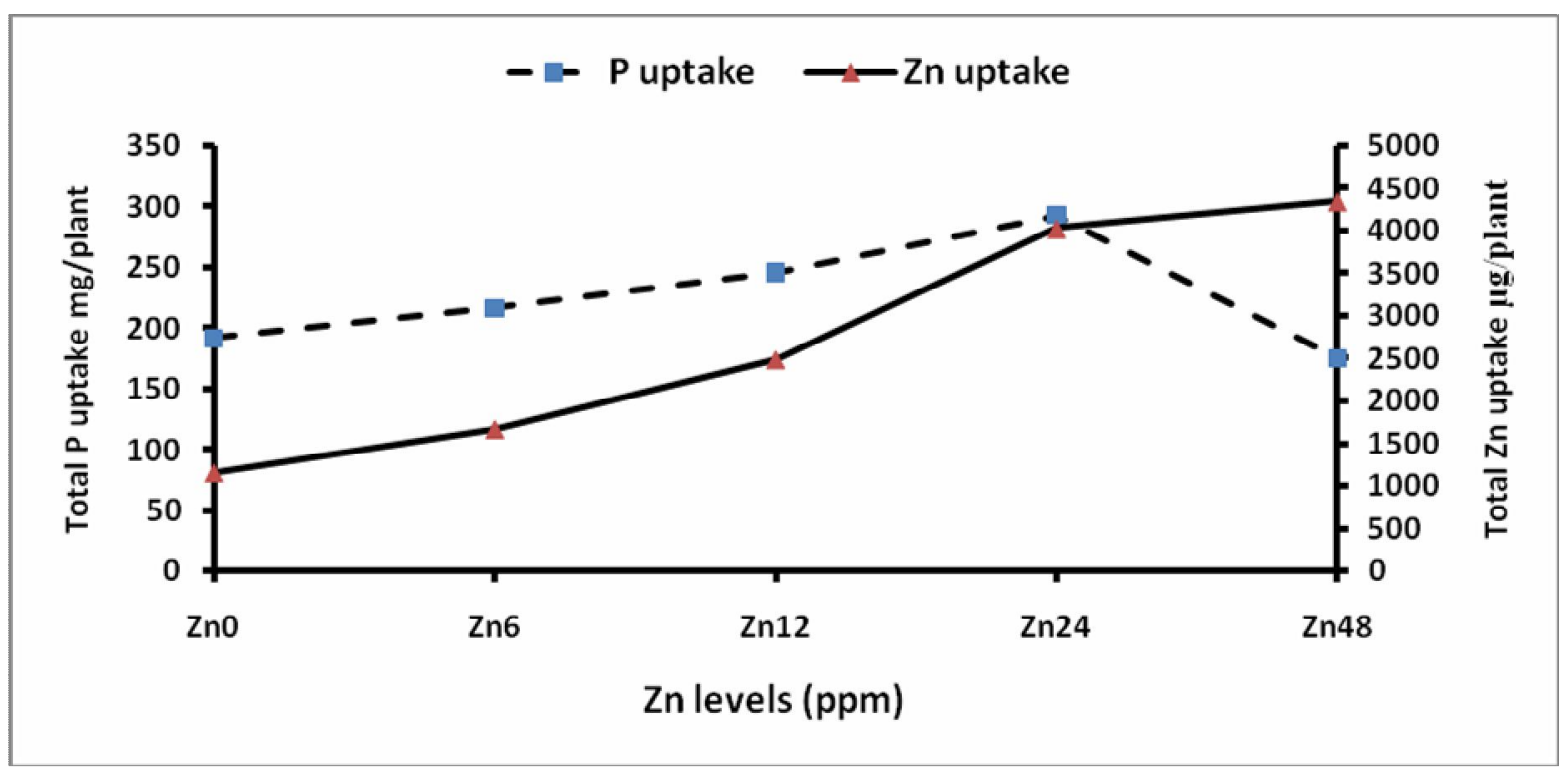

Fig.5. Relationship between total $P$ and total $Z n$ uptake by plant of night-blooming jessamine as influenced by $\mathrm{Zn}$ fertilization.

References

Balal, R.M.; gimeno, V.; Shahid, M.A.; Lidon, V.; Garcia, A.L.; Abbas, T.; Garcia-Sanchez, F. and Ghazanfer, U. (2011). Effects of phosphorus fertilization on growth, leaf mineral concentration and xylem-phloem nutrient mobility in to rootstocks of prunus in the Mediterranean area.
Australian J. Crop Sci., 5 (12): 1542-1549.

Barben, S.A.; Hopkins, B.G.; Jolley, V.D.; Webb, B.L. and Nicholas, B.A. (2010). Phosphorus and zinc interaction in chelatorbuffered solution grown Russet Burbank potato. J. Plant Nutr., 33: 587-601.

Bukvicl, G.; Antunovic, M.; Popovic, S. and Rastijo, M. (2003). Effect of 
$\mathrm{P}$ and $\mathrm{Zn}$ fertilization on biomass yield and its uptake by maize lines (Zea mays, L.). Plant Soil Environ. 49 (11): 505-510.

Cakmak, I. and Marschner, H. (1987). Mechanism of phosphorusinduced zinc-deficiency in cotton. III- Changes in physiological availability of zinc in plant. Physiol. Plant. 70: 13-20.

Carolina, A.; Vasconcelos, F.D.; Williams, C.; Nascimento, A. and Fernando, F.C.F. (2011). Distribution of zinc in maize plants as a function of soil and foliar $\mathrm{Zn}$ supply. Inter. Res. J. Agric. Sci., 1 (1): 1-5.

Das, K.; Dang, R.; Shivananda, T.N. and Sur, P. (2005). Interaction between phosphorus and zinc on the biomass yield and yield attributes of the medicinal plant stevia (Stevia reboudiana). Science World J., 5: 390-395.

Dawdy, S. and wearden, S. (1983). Statistics for Research. John Wiley and Sons, New York.

Dell, B. and Wilson, A.S. (1985). Effect of zinc supply on growth of three species of eucalyptus seedlings and wheat. Plant Soil, 88: 377384.

El-Gharably, G.A. and Rushdi, M.K. (1975). Phosphorus-zinc interaction in cotton nutrition. Assiut $\mathrm{J}$. Agric. Sci., 6 (2): 155-165.

El-Sallami, I.H. (1996). Effect of ethrel and phosphorous application on growth, flowering and uptake of some nutrients in Viola odorata, L. Assiut J. Agric. Sci., 27 (3): 45-59.

El-Sallami, I.H. (1997). Response of Narcissus tazetta, L. to some micronutrients and methods of application. Egypt. J. Appl. Sci., 12 (1): 256-276.

El-Sallami, I.H. (2001). Growth, flowering and nutrient uptake of $\mathrm{Se}$ - neciaocruentus, L. plants as influenced by phosphorus-zinc interaction. Assiut J. Agric. Sci., 32 (1): 175-198.

Fageria, V.D. (2001). Nutrient interactions in crop plants. J. Plant Nutrition, 24 (8): 1269-1290.

Gianquinto, G.; Abu-Rayyan, A; Tola, L. D.; Piccotino, D. and Pezzarossa, B. (2000). Interaction effects of phosphorus and zinc on photosynthesis, growth and yield of dwarf bean grown in two environments. Plant and Soil 220:219-228

Huang, C.Y., Barker, S.J., Langridge P., Smith, F.W. and Graham, R.D. (2000). Zinc deficiency upregulates expression of highaffinity phosphate transporter genes in both phosphatesufficient and-deficient barley (HordeumvulgareL.cv.Weeah) roots. Plant physiol., 124:415422.

Jackson, M.L. (1978). Soil Chemical Analysis. Fall Indian Private, Ltd. New Delhi.

Kato, T. and Takel, A. (1989). Studies on available soil phosphorus in horticultural crops. II- Effects of available soil phosphorus on growth and yield of chrysanthemum. Bull. Aichiken Agric. Res. Center, 21: 230-238. Hort. Abst. 61: 3874 .

Khan, A.A. and Zende, G.K. (1977). The site for $\mathrm{Zn}-\mathrm{P}$ interactions in plants. Plant and Soil, 46: 259262.

Khorgamy, A. and Farnia, A. (2009). Effect of phosphorus and zinc fertilization on yield and yield components of chick pea cultivars. African Sci. Conference Proc., 9: 205-208.

Kinaci, G. and Kinaci, E. (2005). Effect of zinc application on quality traits of barley in semi arid zones 
of Turkey. Plant Soil Environ., 51 (7): 328-334.

Leopold, A.C. and P.E. Kriedemann (1980). Plant Growth and Development. $2^{\text {nd }}$ ed. Tata McGrawHill Publishing Company LTD., New Delhi.

Lu, Z.G., Grewal, H.S. and Graham, R.D. (1998). Dry matter production and uptake of zinc and phosphorus in two oilseed rape genotypes under differential rates of zinc and phosphorous supply. J. Plant Nut., 21:25-38.

Mirvat, E.G.; Mohamed, M.H. and Tawfik, M.M. (2006). Effect of phosphorus fertilizer and foliar spraying with zinc on growth, yield and quality of groundnut under reclaimed sandy soils. J. App. Sci. Res., 2 (8): 491-496.

Mohamed, R.A.; Abd El-Aal, H.A. and Abd El-Aziz, M.G. (2011). Effect of phosphorus, zinc and their interaction on vegetative growth characters, yield and fruit quality of strawberry. J. Hort. Sci. \& Ornamental Plants, 3 (2): 106-114.

Mohamed, S.M. (1992). Effect of different phosphorus and zinc application on growth and flowering of Gerbera jamesonii, Hook plants. Annals of Agric. Sci., Moshtohor, 30 (3): 1425-1439.

Moraghan, J.T. and Grafton, K.F. (2003). Plant zinc and the zincefficiency trait in navy bean. J. Plant Nutr., 26 (8): 1649-1663.

Mousavi, S.R. (2011). Zinc in crop production and interaction with phosphorus. Australian J. Basic and Appl. Sci., 5 (9): 1503-1509.

Nasiri, Y.; Zehtab, S.S.; Nasrullahzadeh, S.; Najafi, N. (2010). Effects of foliar application of micronutrients (Fe and $\mathrm{Zn}$ ) on flower yield and essential oil of chamomile (Matricariachamomilla, L.). J. Medicinal Plant Res., 4 (17): 1733-1737.

Obaid, E.A. and Al-Hadethi, M.E. (2013). Effect of foliar application with manganese and zinc on pomegranate growth, yield and fruit quality. J. Hort. Sci. \& Ornamental Plants, 5 (1): 41-45.

Omer, E. A. (1992). Effect of zinc and manganese spraying on the growth, yield, essential oils and pigments of Tagetespatula. Bull NRC, 17 (4): 205-212.

Sharma, K.; Krants, B.A.; Brown, A.L. and Quick, S. (1968). Interaction of $\mathrm{Zn}$ and $\mathrm{P}$ in top and root of corn and tomato. Agron. J., 60: 452-456.

Stukenholts, D.D.; Olsen, R.L.; Gogen, G. and Olsen, R.A. (1966). On the mechanism of phosphoruszinc interaction in corn nutrition. Soil Sci. Soc. Amer., 30: 759763.

Webb, M.J. and Loneagan, J.F. (1988). Effect of zinc deficiency on growth, phosphorus concentration and phosphorus toxicity of wheat plants. Soil Sci. Soc. Amer., 52: 1676-1680. 
استجابة نباتات مسك الليل للعلاقة بين الفوسفور و الزنتك

1 -النمو والإزهار و المحتوى الممتص من الفوسفور و الزنتك

اسماعيل حسن السلامى و محمد مصطفى جاد

قسم الزينة -كلية الزراعة -جامعة أسيوط

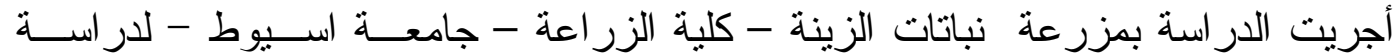

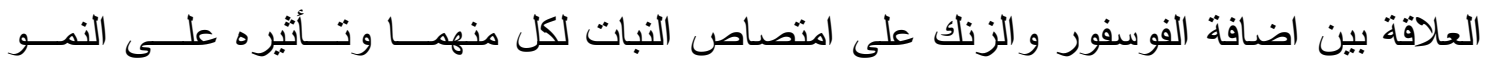

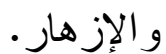

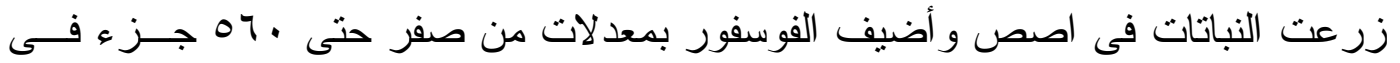

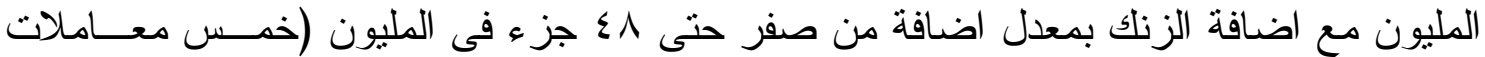
ل اكل منها).

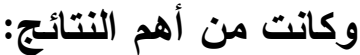

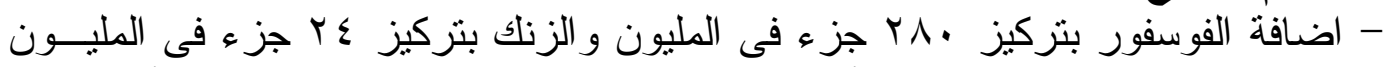

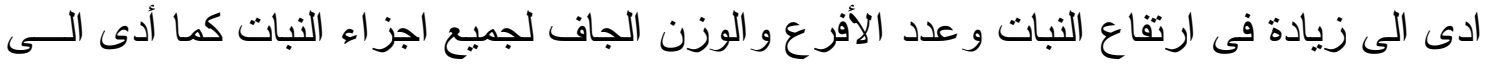
تبكير الإزهار وزيادة فترة بقاءها على النى النبات.

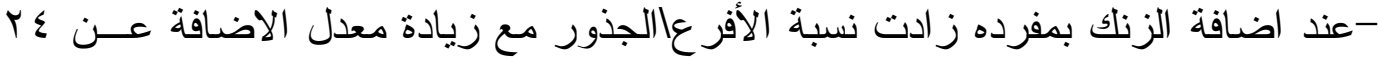

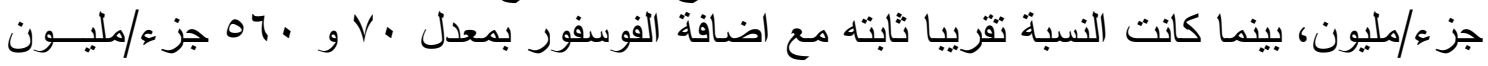
مع مستويات الزنلك المختلفة.

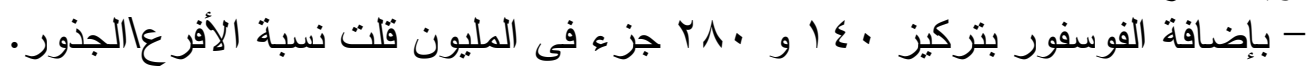

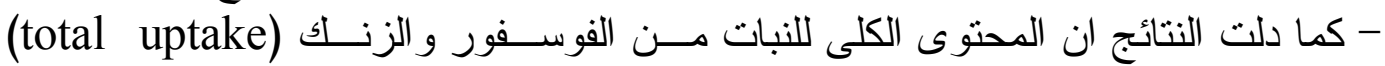

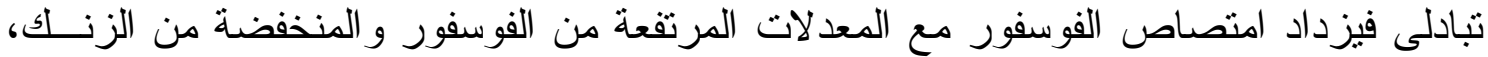
وعلى العكس مع المحتوى الكلى للزئلك.

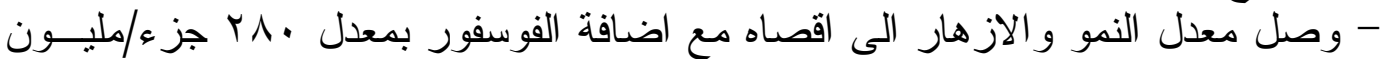

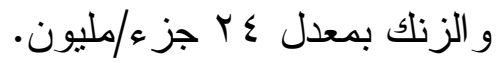

